\title{
RESEARCH
}

\section{"METAFUNCTIONS OF LANGUAGE" IN SYSTEMIC FUNCTIONAL LINGUISTICS: A FRAMEWORK FOR THE INTERPRETATION OF MEANING OF TEXT IN SOCIAL CONTEXT}

\author{
Hoang Van Van* \\ VNU University of Languages and International Studies, \\ Pham Van Dong, Cau Giay, Hanoi, Vietnam \\ Received 7 December 2020 \\ Revised 2 February 2021; Accepted 15 July 2021
}

\begin{abstract}
This article is concerned with how "metafunctions of language" is theorized by M.A.K. Halliday in his Systemic Functional Linguistics (SFL) theory, and how the metafunctional framework can be used to analyse and interpret the meaning of text in social context. The paper consists of five sections. Section one introduces the topic of the article. Section two briefly examines the notion of "functions of language" in formal and non-systemic functional (non-SF) models of language. Section three explores in some detail the notion of "metafunctions of language" in the SFL model. The study shows that unlike formal and non-SF models of language, SFL conceptualizes metafunctions of language not just as "uses of language" but as a fundamental property of language itself. To illustrate the applicability of the metafunctional framework to the interpretation of meaning of text in social context, Section four conducts an analysis of two stanzas in the famous Vietnamese poem "Hai sắc hoa ti-gôn" (Two Colours of Antigone) in terms of experiential, interpersonal, textual, and logical meanings. Section five provides a résumé of the issues studied in the article, pointing out the advantages of Halliday's metafunctional framework. The study aims to contribute to our understanding of language as a system of metafunctions, opening up vast potential for the application of the SFL model to language teaching, learning, and research.
\end{abstract}

Key words: formal and non-SF models, metafunctions of language, SFL, meaning of text in social context

\section{Introduction}

For many people, when asked the question: "What function does language have?", the answer would normally be, "It has the function of communicating information". Communicating information is perhaps the most visible function of language that anyone could readily notice. This way of understanding about the function of language is not wrong but incomplete. This is because if understood in this way it would seem that language has only one single function. A closer inspection of any natural language, however, will reveal that language is "multifunctional" (Halliday \& Hasan, 1989, p. 23). Now, if we accept the view that language is multifunctional, the next question that arises at once will be: "What and how many

\footnotetext{
* Corresponding author

Email address: vanhv@vnu.edu.vn; vanhv.sdh@gmail.com

https://doi.org/10.25073/2525-2445/vnufs.4750
} 
functions does language have?" Different scholars seem to offer different answers to the question. There are scholars who answer the question implicitly, integrating functions of language into their definitions of the sentence. In contrast, there are other scholars who address the question explicitly, identifying specific functions of utterances which occur in specific situations such as greeting, offering, complimenting, criticizing, thanking, etc.; and there are still other scholars who attempt to approach the problem in some general manner, conceptualizing functions of language through the general roles they serve in communication. The rest of the article is organized as follows. Section 2 will briefly examine some foremost formal and non-SF models of functions of language. Specifically, it will delve into what we would like to refer to as "the traditional grammar models", "the pragmatics model", "the Malinowski model", "the Bühler model", "the Jakobson model", "the Morris model", and "the Britton model". Section 3 will present in some detail how the metafunctional framework is conceptualized by the renowned British-born Australian linguist M.A.K. Halliday in his SFL model. To illustrate the applicability potential of the SFL metafunctional framework to the interpretation of meaning of text in social context, Section 4 will present an analysis of some parts of the Vietnamese poem "Hai sắc hoa ti-gôn" (Two Colours of Antigone). Section 5 provides a résumé of the issues discussed, and points out the advantages of Halliday's metafunctional framework both in theoretical conceptualization and practical applicability to language teaching, learning, and research.

\section{Functions of Language in Formal and Non-SF Models}

\subsection{The Formal Grammar Models}

It is often claimed that formal grammars are concerned only with language structures, with the syntagmatic axis in de Saussure's (1983) formulation. But it is not quite true. The following definitions of the sentence taken from various sources by formal grammarians, both foreign and indigenous Vietnamese, will somehow serve to prove the point:

A sentence is a complete unit of speech which is constructed in accordance with the grammatical rules of a language, acting as the most important vehicle for structuring, reflecting and conveying ideas. In the sentence not only is there an expression of ideas but also a relationship between the speaker and reality. ${ }^{1}$ (Vinagradov, 1954, as cited in K. T. Nguyễn, 1964, p. 147) (...) a sentence is a linguistic level which is grammatically and semantically complete and is constructed with an intonation in accordance with the rules of a language; it is a means for expressing and conveying ideas about reality and about the attitude of the speaker towards reality. ${ }^{2}$ (T. P. Hoàng, 1980, p. 19)

\footnotetext{
${ }^{1}$ This passage appears in the Vietnamese original (page 147) as follows:

Câu là một đơn vị hoàn chỉnh của lời nói được hình thành về mặt ngữ pháp theo các quy luật của một ngôn ngữ nhất định, làm công cụ quan trọng nhất để cấu tạo, biểu hiện và truyền đạt tư tưởng. Trong câu không phải chỉ có sự truyền đạt về hiện thực mà còn có cả mối quan hệ của người nói và hiện thực.

2 This passage appears in the Vietnamese original (page 19) as follows:

(...) câu là ngữ tuyến được hình thành một cách trọn vẹn về ngữ pháp và về ngữ nghĩa với một ngữ điệu theo các quy luật của một ngôn ngữ nhất định và phương tiện diễn đạt, biểu hiện tư tưởng về thực tế và về thái độ của người nói đối với hiện thực.
} 
A sentence is a linguistic unit which has an independent grammatical structure (internal and external) and a terminal intonation contour, expressing a relatively complete thought, and may contain an evaluation of reality by the speaker which helps to form and convey ideas. ${ }^{3}$ (Diệp, 1987, p. 19)

A simple sentence (emphasis in original) is one that is made up of only one independent clause. An independent clause is formed from a noun phrase subject that names the topic of the sentence, and a verb phrase predicate. If the main verb is an action verb, the purpose of the sentence is to describe an action. If it is a stative verb, the purpose is to state a description. If the main verb has a modal, the purpose of the sentence is to express an attitude or opinion about an event or condition. (Wilson, 2007, p. 540)

A sentence is a unit of speech whose grammatical structure conforms to the laws of the language and which serves as the chief means of conveying a thought. A sentence is not only a means of communicating something about reality but also a means of showing the speaker's attitude to it. (Kaushanskaya et al., 2008, p. 264)

As can be seen from the above definitions of the sentence, besides the grammatical and phonological characteristics that can be observed such as "grammatically and semantically complete", "independent grammatical structure", "grammatical structure", "made up of one independent clause", "terminal intonation", we can find the functional features that are expressed in such phrases as "conveying ideas about reality", "communicating something about reality", "expressing a relatively complete thought", "express an attitude or opinion about an event or condition", and "showing the speaker's attitude". It is clear from the above definitions of the sentence that formal grammars do recognise functions of language. But what seems to be a problem with these definitions of the sentence is that functions of language are not explicitly specified, making it difficult to understand what they are, what they look like, and, in particular, how many functions language has.

\subsection{The Pragmatics Model}

The following natural parent-child exchange in Vietnamese (field-noted by the author of this article) would hardly draw a notice of the formal grammarian, but it would certainly attract the attention of the functional grammarian for it would lead to insights about our abilities to use language. A father, intent on viewing something in his iPhone, was interrupted by his four-year-old son, eager to borrow his father's iPhone to view some favourite children's programmes on YouTube:

Son: Bố cho con mươn [điện thoại] đi-i-i! (Dad, let me borrow [your iPhone], please.)

Father: Bố đang xem. (I'm viewing.)

If we examine closely this simple exchange in the immediate context in which

\footnotetext{
${ }^{3}$ This passage appears in the Vietnamese original (page 5) as follows:

Câu là đơn vị của ngôn ngữ, có cấu tạo ngữ pháp (bên trong và bên ngoài) tự lập và ngữ điệu kết thúc, mang một tư tưởng tương đối trọn vẹn và có thể kèm theo sự đánh giá hiện thực của người nói, giúp hình thành và biểu hiện, truyền đạt tư tưởng.
} 
it occurs, a noticeable fact emerges: the second speaker - the father - does not seem to cooperate (in the Gricean sense) with the first speaker - the son. Looking simply at the words on the page from the point of view of formal grammar, however, we can see that the two utterances in the exchange are simple sentences; the first is an imperative sentence which can be analysed in formal terms as Subject $(B o ̂ ́)+$ Verb (cho con muoọn $)+[$ Object (diện thoại) $]+$ imperative particle ( $(i)$; and the second is a declarative one which can be analysed as Subject $(B o ̂ ́)+$ Verb (đang xem). Until now, this formal approach to the analysis of language still prevails in the academic world and in primary, secondary, and tertiary classrooms as well. Is this a sound approach to language analysis? The normal answer to this question is "Yes, it is; but inadequate" for it fails to account for the purposes the two speakers want to achieve by their utterances. To be more specific, it fails to account for human beings' ability to translate what is structurally an imperative sentence (the son's utterance) into what is functionally a request and a declarative sentence or a statement of fact (the father's response) into what is functionally a decline of a request. Nor does it take into account the father's ability to make an oblique answer: by stating that he is viewing, the father refuses the son's request to borrow his iPhone. In other words, there is more to a speaker's knowledge of his language than a knowledge of the structure of the code. A speaker must know how to use his language; he must know how to exploit the resources of his language so that he can make it work for him. In other words, he must know the functions of his language (cf. Halliday, 1970, 1973, 1975, 1978). This approach to the analysis of language affirms the idea that "A statement, spoken in real life, is never detached from the situation in which it has been uttered. For each verbal statement by a human being has the aim and function of expressing some thought or feeling actual at the moment and in that situation" (Malinowski, 1923, p. 307): when we say something, we do something (Austin, 1962; Searle, 1969), and when we say something, we want to achieve a function or a (communicative) purpose (Halliday \& Hasan, 1989; Hasan \& Perrett, 1994; Thompson, 2014). This is perhaps one of greatest achievements pragmatics has contributed to modern linguistics.

\subsection{The Malinowski Model}

Malinowski, whose influence on British functional linguistics is considerable, represents an anthropological school of thought in which language played a much more significant role. His position in British functional linguistics can in some ways be likened to that of Boas and Sapir in American descriptive linguistics in the USA. Like Boas, Malinowski was convinced that field work demanded familiarity with the tribal language. At the same time, he believed that an understanding of the language was impossible without constantly relating it to the culture in which it was operative. In his famous supplement (Supplement I) to an influential philosophical work of the early nineteen twenties by Ogden and Richards (1923) which explored the relations between language, thought, and reality entitled The Meaning of Meaning: A Study of the Influence of Language upon Thought and of the Science of Symbolism, Malinowski (1923) laid the foundation for research on functions of language. His eloquent argument for the close relationship between language and culture can be seen in the following quotes:

"... language is essentially rooted in the reality of the culture, the tribal life and customs of the people, and ... it cannot be explained without constant reference to these broader 
contexts of verbal utterance" (1923, p. 305).

"[An utterance] becomes only intelligible when it is placed within its context of situation". ... the situation in which words are uttered can never be passed over as irrelevant to the linguistic expression" (1923, p. 306).

"A statement, spoken in real life, is never detached from the situation in which it has been uttered. For each verbal statement by a human being has the aim and function of expressing some thought or feeling actual at that moment and in that situation" (1923, p. 307).

Approaching language from the ethnographer's perspective and using context of situation as the central concept, Malinowski was able to identify four main uses (functions) of primitive language. The first use of language is speech of action speech used by fishermen during a fishing expedition in the Trobriand Islands where Malinowski did field work. The second is narrative: "incidents are told or discussed among a group of listeners, ... to create new bonds and sentiments by the emotional appeal of the words". Malinowski claimed that narrative is primarily a mode of social action rather than a mere reflection of thought. A narrative can be either directly or indirectly associated with one situation to which it refers. The third use of language is phatic communion. It is "a type of speech in which ties of union are created by a mere exchange of words" (op.cit., p. 315). Malinowski claimed that words in phatic communion are used to fulfil a social function and "language appears to use in this function not as an instrument of reflection but as a mode of action" (op.cit., p. 315). The fourth use of language in Malinowski's model is the ritual use of words in word magic and the use of spells. Malinowski's model has influenced greatly the London school of linguistics, in particular on Firth's (1957, 1968) ideas of language, and later on Halliday's Systemic Functional Linguistics model.

\subsection{The Bühler Model}

From another perspective, based on Plato's conceptual framework of rhetorical grammar which distinguished first person, second person, and third person, the famous German-born Austrian psychologist and linguist, Carls Bühler (1934) developed a functional model of communication known as the "organon model". In this model, Bühler identified three functions of language which are referred to respectively as expressive function (Ausdrucksfunktion), conative

function (Appellfunktion, i.e. appealing function), and representational function (Darstellungsfunktion). The expressive function, according to Bühler (1934), is language that is oriented towards the self, the speaker; the conative function being language that is oriented to the addressee; and the representational function being language that is oriented towards the rest of reality. Bühler's organon model was widely accepted by scholars of the Prague school of linguistics (Halliday \& Hasan, 1989). In particular, his organon model was adopted and expanded by the famous Russian-born American linguist Roman Jakobson.

\subsection{The Jakobson Model}

Jakobson (1960), based a classification of functions on the model of the communication process in which a speaker and a hearer in a speech event (for example, a conversation, discussion) exchange messages, developed a model of functions of language which distinguishes six attendant elements or factors of communication, that are necessary for communication to occur: (1) context, (2) 
addresser (sender), (3) addressee (receiver), (4) contact, (5) common code, and (6) message. Each factor is the focal point of a function, that operates between the message and the attendant factor. Briefly, Jakobson's model of six functions of language are the following, in order:

1. The referential function, a predominant function of language, is oriented towards the context of the speech event. It relates to the ability of language to impart ideas about a situation, a thing or a mental state as in the statement The earth moves around the sun.

2. The emotive or expressive function highlights the addresser's feelings as in the interjection $\mathrm{Oh}$ !

3. The conative or directive function focuses on the person addressed. This function is expressed grammatically as vocative (calling the attention of the person spoken to such as David in David, come here please.) and the imperative (requesting or requiring the addressee to perform some action such as Hurry up!).

4. The phatic function indicates that the addressee is well-disposed and favourably inclined toward the addressee. This function serves to establish, prolong or discontinue communication as in Hello, how are you?

5. The poetic function centres on the message itself. It is the most important function in poetry. It relates to the verbal art and the aesthetics of language.

6. The metalingual function focuses on the linguistic code - the use of language to discuss language itself. This function is used to establish mutual agreement on the code; for example, What do you mean by "social context"?

\subsection{The Britton Model}

So far, we have outlined several models of language functions which are concerned primarily with spoken language. We now turn our attention to examining a model of language functions that is concerned mainly with the functions of the written word - the Britton model. As with the Jakobson model, the Britton model drew on the Bühler model, but it was developed to serve language teaching and learning purposes.

In a lucid and succinct book entitled Language and Learning, the British educationalist James Britton (1993), in the course of classifying 2122 pieces of writing from 500 boys and girls aged from eleven to eighteen, proposed his own model of three language functions which are referred to respectively as expressive function, transactional function, and poetic function. According to Britton (1993), the expressive function (expressing personal attitudes, feelings, reasons, reactions, etc.) is the starting point in one's linguistic experience. It is the neutral ground from which one moves out to meet the demands made by larger language needs. When the needs of the moment call for action to be taken, the expressive function gives way to the transactional function which is concerned with one's use of language to do something. In the transactional function, communicators participate in informing, analyzing, planning, teaching, arguing, persuading, or any other kinds of activity where a practical outcome is to be achieved. And when the interest focuses on the form and shape of a linguistic experience for its own sake, rather than on what is accomplished, we find the expressive function shifting ground to the poetic function. Here the role of the writer is more that of spectator. By standing detached from a linguistic experience, the spectator can evaluate it in terms of the larger value systems it holds for him. Thus released from 
the need to achieve an outcome or interact with another participant, the writer as spectator can be free to attend to the linguistic experience as linguistic experience: the forms and structures of individual utterances and the discourse as a whole. The language expressed by the poetic function might also be called "verbal art". Britton maintained that for the child beginning to write, the expressive function is the natural starting point. It is the dominant function in our daily interchanges with others. It is a neutral point from which a process of increasing differentiation would take place towards the utility of the transactional mode on the one hand or the self-consciously formal mode of the poetic on the other. (For more detail about these three language functions in the Britton model, see Britton, 1993: Chapters 1, 3, and 4).

\subsection{The Morris Model}

In his entertaining book entitled The Naked Ape, Morris (1999) studied language functions from an animal behaviourist's point of view. He recognized four main language functions: information talking, mood talking, exploratory talking, and grooming talking. Information talking, according to Morris (1999, p. 203), is the method of communication which enabled primitive people to refer to the objects in the environment and also to the past and the future as well as to the present. This is the most important human communication function of language for it involves a collaborative communication exchange between speaker and listener. Morris suggests that the function of information talking seems to appear first, although in the child's history of development it appears last of all. Information talking has evolved, but it doesn't stop there. It has added a number of additional functions, one of which is mood speaking - a form of speech that expresses a speaker's mood and attitude. Mood speaking can be non-verbal mood signals; but these messages can be augmented with verbal confirmation of our feeling; for example, a yelp of pain is closely followed by a verbal signal that "I am hurt" or a roar of anger is accompanied by the message "I am furious". Exploratory talking is a third language function. This is "talking for the sake of talking, aesthetic talking, or play talking". And groom talking refers to "the meaningless, polite chatter of social occasions"; for example, "Nice weather today, isn't it?" or "Have you read any good books lately?" Morris (1999, p. 204) noted that grooming talking is "not concerned with the exchange of important ideas or information, nor does it reveal the true mood of the speaker, nor is it aesthetically pleasing. Its function is to reinforce the greeting smile and to maintain the social togetherness. It is "the most important substitute we have for social grooming" (Morris, 1999, p. 206); it is used to oil the social process and to avoid friction (Halliday \& Hasan, 1989, p. 16) so that communicators can carry out their conversations naturally and smoothly.

\subsection{Summary}

The conceptualization of language functions in formal and non-SF models of language presented above allow the following remarks:

First, although these models seem to be differently formulated, and each one uses different terminologies, they all have the following features in common: they all recognize that language is multifunctional, reflected in three aspects (i) language is used to talk about things (informative, narrative, representational, expressive); (ii) language is used for interactional purposes "between speaker and listener, writer and reader", expressing the self and influencing others (expressive, mood, conative, active); and (iii) language is used to express imaginative or aesthetic function (see Halliday \& Hasan, 1989). 
Secondly, the demands of human beings for language as speakers or writers, listeners or readers are diverse. Therefore, what functions and how many functions language has depend largely on the perspective of the researcher. What is presented above shows that the problem of functions of language is approached from different perspectives: ethnographical, psychological, communicational, educational, biological, and so on. Therefore, it would not be surprising to see that if the researcher looks at the problem of language functions from the point of view of ethnography, and is more interested in linguistic functions, then he or she will adopt the functions of language as recognized in the Malinowski model. In contrast, if the researcher approaches the problem of language functions from the psychological point of view, and views language as being used to serve the life of the individual in the community, he or she will arrive at formulating a model of language functions like the Bühler organon model. If the researcher approaches the problem of language functions from the point of view of the communication process in which a speaker and hearer in a speech event exchange messages, he or she will arrive at the Jakobson model. If the researcher is interested in the problem of language functions from the educational perspective, then he or she must classify language functions into the transactional, the expressive, and poetic functions as they are detailed in the Britton model. And if the researcher wishes to tackle the problem of language functions from the point of view of the evolution of communication in biology, then he or she will adopt the Morris model, classifying language functions into information talking, mood talking, exploratory talking, and grooming talking.

And thirdly, what seems to be a problem with most of such above models is that they were essentially constructed on a kind of conceptual framework in nonlinguistic terms, looking at language from the outside, and using this for interpreting the different ways in which people use language. And as Halliday \& Hasan (1989, p. 17) have aptly put it, "In all these interpretations of functions of language, function equals use: the concept of function is synonymous with that of use". This way of conceptualization of language functions is unable to characterize language as a system. "For a theory to be functional in the proper sense of the word, the term function needs to be more abstract than function equated with specific language use. It is only when functions are identified at a high level of abstraction that they can be recognised as essential to all uses of language, becoming the property of the entire linguistic social process as such, that they can be viewed as integral to the system of language, serving to explain the nature of its internal structure by relation to its social uses" (Hasan \& Perrett, 1994, p. 183). With these remarks, we now turn to explore the notion of "metafunctions of language" in Systemic Functional Linguistics.

\section{The SFL Model}

Among the scholars who study language functions, Halliday is perhaps the foremost writer. He has developed a world famous linguistic theory known as Systemic Functional Linguistics in which he incorporates the social dimension into his linguistic theory, connecting children's functions of language with adults' generalized functions of language. It is precisely his model of functions of language that we will consider below.

\subsection{Children's Functions of Language}

In his studies of children's language development, Halliday (1973, 1975) made two important observations. First, young children's proto-languages are semiotic systems of the primary kind: they are systems with two levels only - content and 
expression - and lack a level of lexicogrammar. Secondly, children early on acquire a wide range of functions, but typically each of their utterances serves only one function. For Halliday, to say that a child knows language is to say that he or she knows how to mean, how to use language to perform these functions. Halliday (1975, pp. 18-20) recognized seven distinct functions early in a child language development:

1. Instrumental (the "I want" function of language): language as a means by which the child satisfies his material needs or requirements. Example: Mum, I want that cake.

2. Regulatory (the "do as I tell you" function): language used to influence and control the behaviour of others. Example: Let's play this game.

3. Interactional (the "me and you" function): language as a means of maintaining ties with other people. It reveals the child's awareness of others and his relation to them. Example: the greeting, Hello, dad, and also the response, Yes.

4. Personal (the "here I come" function): language for expressing one's own individuality and for developing awareness of the self and of personality. Example: Yeah. They are mine, not yours.

5. Heuristic (the "tell me why" function): language as a means of exploration, both inside and outside oneself; language used to discover and learn about things. Example: Daddy. What are roots used for?

6. Imaginative (the "let's pretend" function): language used to create one's own world or environment, including meaningless sounds, rhyming and other linguistic play. "Story" and "pretend" and "make up" become elements of the imaginative function. Example: (a child says about her elder brother Jim: Naughty, naughty, boydy, naughty Jimy.

7. Informative (the "I've got something to tell you" function): language used to communicate information to someone who does not already possess that information, to express propositions and to convey a message which makes reference to the world surrounding the child. Example: Daddy has gone to work.

According to Halliday (1975), children are motivated to develop language because it serves certain purposes or functions for them. The first four functions help them to satisfy physical, emotional and social needs. The next three functions help them to come to terms with their environment, to ensure their survival and to take their place in interactional communication. Halliday (1975, p. 21) noted: "The young child has a very clear notion of the functions of his own linguistic system. He knows very well what he can do with it. But what he can do with it is not at all the same thing as what the adult does, still less as what he thinks he does, with his linguistic system".

\subsection{Grown-Ups' Generalized Functions of Language}

Halliday (1975) claims that as children move into the mother tongue, the seven functions mentioned above give way to the generalized functions of language. In this process, in between the two levels of the simple proto-language system: content and expression, an additional level of content is inserted. Instead of one level in the content plane, adult language now has two: semantics and lexicogrammar. The expression plane now also consists of two levels: phonology and phonetics. These planes of content and expression of adult language in relation to social context can be presented in Figure 1 below: 


\section{Figure 1}

Levels of Language in Relation to Social Context (V. V. Hoang, 2018b, p. 4)

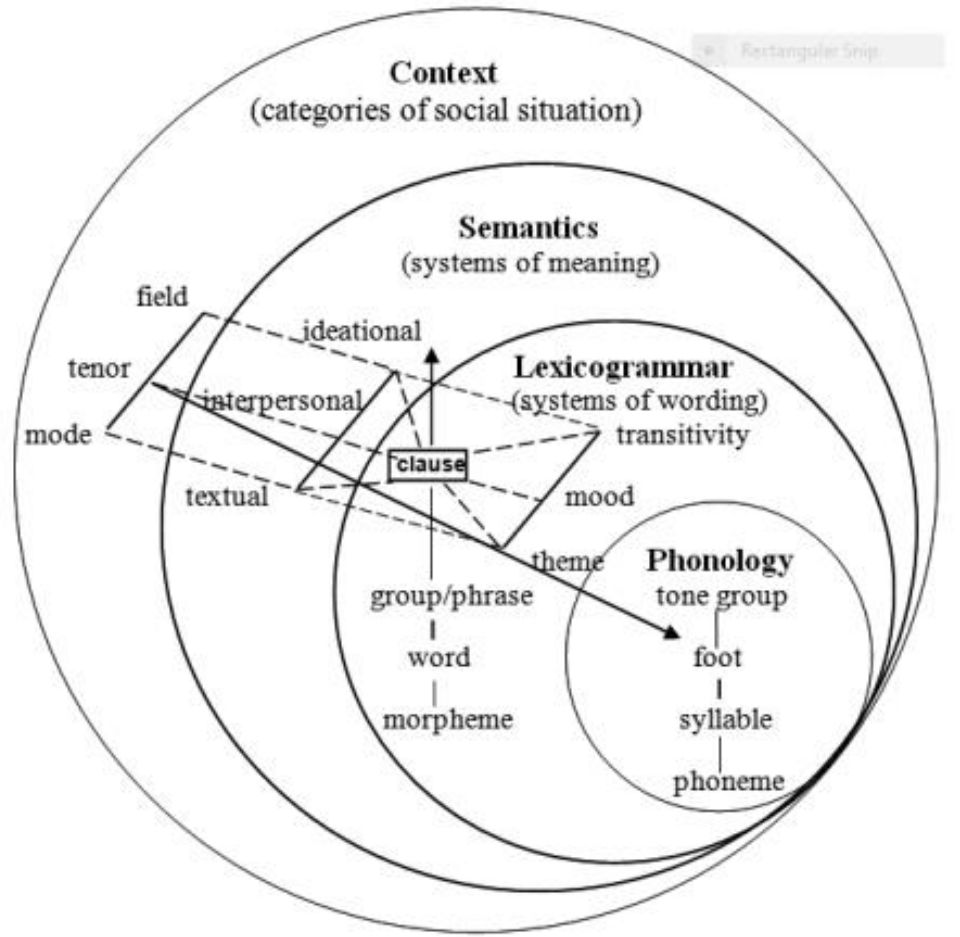

Figure 1 shows that adult language is multifunctional. Halliday (1978 and elsewhere) claims that every utterance does several things at once, in an integral way. $\mathrm{He}$ recognizes three generalized functions of language which he calls "metafunctions": (1) ideational metafunction, interpersonal metafunction, and (3) textual metafunction. Since detailed discussions of these are available (e.g. see Halliday, 1970, 1978, 1985, 1998; Martin, 1992; Matthiessen, 1992, 1995; Halliday \& Hasan, 1989; Hasan, 2011; Halliday \& Matthiessen, 2014; V. V. Hoang, 2012, 2018a, 2018b), only a brief account of each metafunction is provided here.

The first metafunction - the ideational - has two components: the experiential and the logical. The experiential metafunction of language is the resource speakers/writers draw on to construe their experience of the world - both the real world of physical phenomena and the inner world of their consciousness, feelings, beliefs, and reflections. Human language acts as resources for the construal of classes of things (e.g. "autumn", "twilight", "petal"); qualities (e.g. "beautiful", "lovely", "good"); quantities (e.g. "one", "each", "some"); doings and happenings (e.g. "pick", "dye", "wait"); behavings (e.g. "laugh", "cry", "kiss"); knowing, feeling, and thinking (e.g. "understand", "love", "think"); sayings (e.g. "say", "tell", "show", "inform"); being, having and being at (e.g. "be", "have", "belong"); and existing (e.g. "appear", "remain") which imply certain participants and incumbent circumstances. These language resources help speakers to construct complex things into groups/phrases (e.g. "a beautiful autumn", "in the glow of the afternoon sunlight"), and groups/phrases into clauses (e.g. "A beautiful Autumn has come"). The logical metafunction is the resource speakers/writers draw on to construe and create relations of phenomena and events such as "x and y" (e.g. "you and I"), "x or y" 
(e.g. "trick or cheat"), "If x [then] y" (e.g. "(If you) drink to me with thine eyes, and (then) I will pledge with mine" (Ben Jonson, as cited in Halliday \& Hasan, 1989, p. 21), "say that x" (e.g. "She said that he was a good teacher", "think that x" (e.g. "He thought that she would come"), and so on.

The second metafunction - the interpersonal - is the resource speakers/ writers draw on to establish and maintain social relations: for the expression of social roles, which include the communication roles created by language itself, the role of questioner and respondent which speakers take on by asking and answering questions (e.g. "Is it hot in Autumn in your country?", "No, it isn't."); and also for getting things done (e.g. "Get out here, please!"). Further, language acts as a potential for the expression of their subjectivity: their expression of probability, obligation, and commitment; their attitudes and evaluation (e.g. "I must go.", "He should have told me about it.").

The third metafunction of language the textual - is the resource speakers/writers draw on to construct "texts" or connected passages of discourse that is situationally relevant (Halliday, 1970, 1978; Halliday \& Hasan, 1976; Martin \& Rose, 2013). It enables listeners/readers to distinguish a text from a random set of clauses or sentences. In any social use of language speakers/writers indicate what information can be taken as Given and what information can be New, what is point of departure - the Theme and what can be the exposition of the point of departure - the Rheme. One aspect of the textual metafunction is concerned with how the various parts of the discourse relate to each other coherently and cohesively: with whether information is presented as retrievable from what has been already been said (i.e. Rheme in the preceding message becomes theme in the succeeding message) is or whether more information is to be presented in the on-going discourse (i.e.
Rheme in the preceding message becomes Theme in the succeeding message). In other words, the textual metafunction is concerned with creating relevance between the parts of what is being said/written, and between the text and the context of situation, "breathing life into language and giving it its sense of realness, cohesion and texture" (Halliday, 1998: xiii; see also Fries, 1981; Halliday \& Hasan, 1989; Martin \& Rose, 2013; V. V. Hoang, 2018a, 2018b).

These three metafunctions - the ideational, the interpersonal, and the textual - work together in individual utterances/clauses, giving rise to three kinds of downward linguistic structure: transitivity, mood, and theme. They are related upwards to three aspects of speech situation which influence the way they are realized in particular instances (see Halliday, 1978): field of discourse, tenor of discourse, and mode of discourse. The field of discourse refers to what is going on in the particular speech situation. It is therefore associated with the ideational metafunction realized in the grammatical patterns and vocabulary denoting "who does what to whom". The tenor of discourse signifies the role relationships of the people involved in the speech situation. It is therefore associated with the interpersonal metafunction realized in the mood (including modality) patterns. And the mode of discourse points to the channel of communication (whether written or spoken or some combination of the two). It is therefore associated with the textual metafunction realized in the theme and information patterns. Taken together, field of discourse, tenor of discourse, and mode of discourse are the social variables which comprise the "register" of a text (Halliday et al., 1964; Halliday, 1978; Halliday \& Hasan, 1989; see also Matthiessen et al., 2010) whose job is to provide the framework for the selection of meanings of the text realized in structural forms. 


\subsection{Metafunctions of Language and the Interpretation of Meaning of Text in Social Context}

"Practice without theory is blind, but theory without practice is empty" (Neubert, 2000, p. 26). We need to illustrate the SFL model of metafunctions at work to see how it can be applied to the interpretation of the meaning of text in social context. To do this, we have chosen the poem "Hai sắc hoa tigôn" (Two Colours of Antigone). There are three reasons for our choice of the poem. First, "Hai sắc hoa ti-gôn" is a famous Vietnamese poem written by an anonymous Vietnamese poetess ${ }^{4}$ (known to readers only by the acronym "TTKh"). Secondly, the poem is written in a simple narrative style whose meanings can be uncovered through linguistic analysis. And thirdly, by using the SFL metafunctional framework for analysis, we can uncover not only the meaning of the poem but also the metafunctional basis of language. The poem consists of eleven stanzas (see Appendix 1). For illustration purposes, however, only the first and a second part of the third stanzas are selected for analysis. We are aware that there may be the danger that some accidental features that are the property of a particular instance of language (the two portions of the poem in this case) will be taken as if they are representative features of grammar in general. But as it will stand, the features that are displayed in the two text portions of the poem can only be accidental in relation to the linguistic system as a whole. So in interpreting them, we will try to relate what we will say about them in general categories that are found in the grammar of the language. We will undertake a two-phase operation: (i) to analyse the two text portions into clause complexes and clause simplexes ("clauses" for short), and their combining patterns to uncover logico-semantic meanings (see Appendix 2); and (2) to analyse the clauses in terms of transitivity, mood, and theme to uncover the ideational, interpersonal, and textual meanings. The notational conventions used for the analysis of the text portions are provided in Appendix 3.

To assist English readers who have limited or no knowledge of Vietnamese, wherever needed, the presentation of each clause is organised into four lines: the first line, which is italicised, provides the Vietnamese wording; the second line gives English inter-glosses; the third line provides the configuration of functions of the elements in the clause, and these functions appear in bold type; and the fourth line provides an English semantic translation. It should be noted that as discourse unfolds, the three metafunctions or strands of meaning are interwoven with each other in a very dense fabric, so that they can achieve all three social metafunctions of language simultaneously (Martin \& Rose, 2013, p. 7). As a way of start, we will begin by examining the experiential metafunction; then we will deal with the interpersonal metafunction, the textual metafunction, and finally the logical metafunction. One more thing that should be noted is that what we are trying to do here is not as a piece of literary commentary but rather as a linguistic exercise in which we identify features that illustrate the general point: that language is metafunctionally organised and that the metafunctional framework can be applied to interpreting the meaning of text in social context.

\subsection{1. Metafunction}

The

Experiential

Let us consider the first stanza of the poem:

\footnotetext{
${ }^{4}$ Whether the writer who composed this poem was a male or a female is unclear. Based on evidence in the text, however, we can guess that the writer was a woman.
} 
||| (1) Một mùa thu trước mỗi hoàng hôn Nhặt cánh hoa rơi \|| (2) chẳng thấy buồn \|

(3) Nhuộm ánh nắng tà qua mái tóc \|

(4) Tôi chờ || (5) người đến với yêu đương.|||

The analysis shows that the stanza is of a seven-beat metre style, a fairly common style in Vietnamese poetry. It is presented in four lines, and according to the convention of traditional layout, each line begins with a capital letter. Structurally, the entire stanza constitutes a clause complex which consists Figure 2 of five clauses. Analyzing the stanza from the point of view of the experiential metafunction (that is, analyzing the content of the stanza in terms of the experience of the outer as well as the inner world of the poetess' consciousness through process types such as material, behavioral, mental, mental, relational, and existential process; their corresponding participants and incumbent circumstances) gives us the result presented in Figure 2 below. ${ }^{5}$

Experiential Meaning of the Stanza

(1)

\begin{tabular}{|c|c|c|c|c|c|c|c|}
\hline$M o ̣ t$ & mùa thu & trước & $m \tilde{\hat{o} i}$ & hoàng hôn & Nhặt & cánh hoa & $r o i$ \\
\hline one & autumn & past & each & twilight & pick & flower petal & fall \\
\hline \multicolumn{3}{|c|}{ Circumstance: time 1} & \multicolumn{2}{|c|}{ Circumstance: time 2} & Process: material & \multicolumn{2}{|l|}{ Goal } \\
\hline
\end{tabular}

At each twilight in a last autumn, (when I picked) picking up a fallen flower

(2)

\begin{tabular}{|l|l|l|}
\hline chẳng & thấy & buồn \\
\hline not & find/feel & sad \\
\hline \multicolumn{2}{|l|}{ Process: relational } & Attribute \\
\hline
\end{tabular}

(I did) not feel sad.

(3)

\begin{tabular}{|l|l|l|l|l|}
\hline Nhuộm & ánh nắng & tà & $q u a$ & mái tóc \\
\hline dye & sunlight & afternoon & through & hair \\
\hline Process: material & Goal & \multicolumn{3}{|l|}{ Circumstance: location } \\
\hline
\end{tabular}

(I dyed) Dyeing the sunlight through the hair/filtering my hair in the glow of the afternoon sun.

(4)

\begin{tabular}{|l|l|}
\hline$T \hat{o} i$ & $c h \grave{o}$ \\
\hline I & wait \\
\hline Actor & Process: material \\
\hline
\end{tabular}

I waited

(5)

\begin{tabular}{|l|l|l|l|}
\hline ngườ & đến & với & yêu đương \\
\hline person & come & with & love \\
\hline Actor & Process: material & \multicolumn{3}{|c|}{ Circumstance: accompaniment } \\
\hline
\end{tabular}

for him to come with (his) love.

\footnotetext{
${ }^{5}$ The capitalized letters of the stanza are retained in our analysis.
} 
As the analysis in Figure 2 indicates, clause (1) begins with two nominal groups Một mùa thu trước (At each twilight) and mối hoàng hôn (in a last Autumn). These nominal elements set local contexts, locating the points of time for the actions and events not only in clause (1), but perhaps in the remaining clauses of the stanza as well (but in our analysis, they are treated as belonging to the first clause). In the SFL model, these nominal groups are assigned the function of Circumstance of time. Following these circumstantial elements is the verb Nhăt (pick). Considering Nhặt alone from the point of view of the experiential meaning, we can interpret it as a type of process, or more specifically, a type of physical action that is tangible when it is performed in reallife situations. This action element of the clause takes on the function of Process: material. Following this material process Nhặt is the nominal group cánh hoa roi (fallen flower), a concrete object that can be observed in real life consisting of the noun cánh hoa and the adjective rot $^{6}$. This nominal group represents the range affected by the action of the verb Nhă or the target that the action Nhăt directs at. This element of the clause, therefore, is assigned the function of Goal.

Clause (2) has a process type which is quite different from clause (1). It begins with the verb thấy (see/feel) - a process which does not express material action like Nhăt but some kind of perceptive mental activity realized in the structure of a relational process (tôi) chẳng thấy buồn (I didn't feel sad). But unlike relational process of the type "x is (a)" or "x has (attribute a)", thấy construes a relational process that expresses the inner emotional state of the poetess which can be assigned the function of Process: relational: inner emotion. Following thấy is buồn (sad), an adjective indicating "negative emotion" (P. Hoang et al., 2002, p. 90) or "an inner state of emotion" (V. V. Hoang, 2012, p. 248) of the Carrier (tôi - which is not present in the clause). It therefore can be assigned the function of Attribute.

Clause (3) has the experiential structure similar to clause (1). Like clause (1), clause (3) starts with the verb Nhuọm (literally, "dye"). Like Nhăt in clause (2), Nhuôm is a type of tangible physical action, and is therefore assigned the function of Process: material. Following Nhuôm is the nominal group ánh nắng tà (the glow of the afternoon sunlight), a kind of observable thing, but not a palpable thing like cánh hoa roi in clause (1). In the SFL model, this observable but not palpable ánh nắng tà is assigned the function of Goal. Following ánh nắng tà is the prepositional phrase qua mái tóc (literally, "through the hair") - the element indicating the location through which the Goal mái tóc is dyed in the sun, and is therefore assigned the function of Circumstance: place. But unlike clause (1) where the two circumstantial elements $M o ̣ t$ mùa thu trước and mỗi hoàng hôn are placed at the beginning of the clause to highlight their thematic prominence, in clause (3) the circumstantial element qua mái tóc is placed at the end of the clause to highlight its rhematic information, and thus giving thematic prominence to the action verb Nhuôm (for more detail on thematic and rhematic information of the Vietnamese clause, see V. V. Hoang, 2007).

Clause (4) begins with the personal pronoun $T \hat{o} i$. Relative to the process $c h \dot{o}, T \hat{o} i$ can be interpreted as the causer or instigator of the action chò, and therefore can be assigned the function of Actor. Moving back to clauses (1), (2) and (3) of the stanza, we can see that $T \hat{o} i$ is not just the element that

\footnotetext{
${ }^{6}$ It should be noted that although roi is normally treated (in dictionaries) as a lexical verb, in this particular context it can be interpreted as an adjective post-modifying the noun cánh hoa.
} 
causes the transitive action of chò in clause (4) chơ nguơi, it is also the agent that causes the transitive action of Nhặt in clause (1) Nhặt cánh hoa rơi, the transitive action of Nhuộm in clause (3) Nhuộm ánh nắng tà, and the element carrying the attribute chẳng thấy buồn (not feeling sad) in clause (2). Following the personal pronoun Tôi indicating the poetess - is the verb chò, a transitive action, and is therefore assigned the function of Process: material. Unlike the transitive material processes in clauses (1) and (3) where the process stops at the Goal cánh hoa rơi and ánh nắng tà, in clause (4) nguoo $i$ - indicating the poetess's ex-lover which is Goal takes part in the next clause: clause (5), functioning as Actor involving in the intransitive action process đến whose function is Process: material. So, here we have two clauses: Tôi chờ người and (người) đến với yêu đương as shown in clauses (4) and (5); and unlike traditional grammar analysis where nguoơi đến với yêu đương is normally assigned the function of object, in the SFL model, it is treated as a separate dependent clause - clause (5).

Clause (5) starts with the personal pronoun người. Considered in relation to đến (come), ngươi can be interpreted as the causer of the action đến, and can therefore be assigned the function of Actor. This element is followed by the verb đến, a tangible intransitive material process, and can be assigned the function of Process: material. This material process is followed by the prepositional phrase vói yêu đưong (with love) which in this context can be assigned the function of Circumstance, but unlike the two Circumstances of time in clause (1) and the Circumstance of place in clause (3), vớ $i$ yê đuong is a kind of circumstance which is encoded as if it were a companion of the Actor nguooi. It therefore can be assigned the function of Circumstance: accompaniment: (Tôi chờ) người đến với yêu đương can be reworded as Người và sụ yêu đương đến (với tôi).
The experiential meaning of the first stanza of the poem realized in transitivity structures can be summarized as follows:

- clause (1) has the configuration of Circumstance of time 1 (Một mùa thu trước $)^{\wedge}$ Circumstance of time 2 ( $m \tilde{\hat{o} i}$ hoàng hôn $)^{\wedge}$ Process: material (Nhặt) $\wedge$ (affected) Goal (cánh hoa roi);

- clause (2): Process: material (chẳng thấy)^ Attribute (buồn);

- clause (3): Process: material $(\text { Nhuộm })^{\wedge}$ (affected) Goal (ánh nắng tà) $\wedge^{\wedge}$ Circumstance of location (qua mái tóc);

- clause (4): Actor $(T o \hat{i}) \wedge$ Process: material $\left(\right.$ chò) ${ }^{\wedge}$ Goal (người);

- clause (5): Actor $($ ngươi $) \wedge$ Process: material (đến) $\wedge$ Circumstance of accompaniment (với yêu đương).

\subsubsection{The Interpersonal Metafunction}

We are now analyzing the stanza from the point of view of the interpersonal metafunction, considering it as a social interactional process in which the communicators take on one of the two basic functions: "giving" or "demanding". The function of giving includes "giving information" realized through a declarative clause or "giving goods- $\&$-services" realized through an interrogative clause; and the function of demanding includes "demanding information" realized also through an interrogative clause or "demanding goods-\&-services" realized through an imperative clause. (For more detail about the nature of the interactive language and the four concepts of "giving", "demanding", "information", and "goods\&-services”, see Halliday (1998, pp. 173-77; Halliday \& Matthiessen, 2014, pp. 134-39). Analyzing the stanza for interpersonal meaning (that is, analyzing the clauses of the stanza in terms of speech functions of the clauses; and their corresponding functions of the elements in terms of Subject, Predicator, 
Complement, and Adjunct) gives us the result presented in Figure 3 below.

Figure 3

Interpersonal Meaning of the Stanza

(1) [Giving information: declarative mood]

\begin{tabular}{|l|l|l|l|l|l|l|l|}
\hline Một & mùa thu & trước & mối & hoàng hôn & Nhặt & cánh hoa & rơi \\
\hline one & autumn & past & each & twilight & pick & flower petal & fall \\
\hline Adjunct 1 & Adjunct 2 & Predicator & Complement \\
\hline
\end{tabular}

At each twilight in a last Autumn, (when I picked) picking up a fallen flower

(2) [Giving information: declarative mood]

\begin{tabular}{|l|l|l|}
\hline chẳng & thấy & buồn \\
\hline not & find/feel & sad \\
\hline \multicolumn{2}{l}{ Predicator } & Complement \\
\hline
\end{tabular}

(I did) not feel sad.

(3) [Giving information: declarative mood]

\begin{tabular}{|l|l|l|l|l|}
\hline Nhuộm & ánh nắng & tà & qua & mái tóc \\
\hline dye & sunlight & afternoon & through & hair \\
\hline Predicator & \multicolumn{2}{|l|}{ Complement } & \multicolumn{2}{|l|}{ Adjunct } \\
\hline
\end{tabular}

(I dyed) Dyeing the sunlight through the hair/filtering my hair in the glow of the afternoon sun.

(4) [Giving information: declarative mood]

\begin{tabular}{|l|l|}
\hline Tôi & chò \\
\hline I & wait \\
\hline Subject & Predicator \\
\hline
\end{tabular}

I waited

The analysis in Figure 3 shows that there is another type of meaning encoded in the stanza - the interpersonal or interactive meaning between communicators (in this case, between the poetess and readers). While in the experiential domain, language has reflective function, in the interpersonal domain, language has enacting function, that of "establishing and maintaining social relations" (Halliday, 1970, p. 143). Looked at from the point of view of the interpersonal meaning, there are two points to note here. First, all the five clauses of the stanza have speech function of "giving information" realized in "declarative mood" in which the
(5) [Giving information: declarative mood]

\begin{tabular}{|l|l|l|l|}
\hline ngươi & đến & với & yêu đương \\
\hline person & come & with & love \\
\hline Subject & Predicator & Adjunct \\
\hline
\end{tabular}

for him to come with (his) love.

poetess takes on the role of one giving the information, describing and asserting the events that happened to her in the past realized in Một mùa thu trước and mỗi hoàng $h o ̂ n$, and the readers (probably including the poetess' ex-lover) are assigned the role of ones receiving the information. Secondly, of the five information-giving clauses, four are realized as declarative: positive (clauses 1, 3, 4 , and 5), and one (clause 2) is realized as a declarative: negative.

The analysis in Figure 3 also shows that the interpersonal elements corresponding to the experiential ones take on different functions, because their jobs 
now are not to represent experience, but to realize the interactive relationships between the information giver and the information receiver. Thus, instead of assigning the clause elements in the experiential domain such functions (taking the material process as representative) as Actor, Process, Goal, and Circumstance, the respective elements in the interpersonal domain are assigned the functions of Subject - the element "by reference to which the proposition can be affirmed or denied" (Halliday, 1998, p. 76; Halliday \& Matthiessen, 2014, p. 145); Predicator - the element which "specifies the process (action, event, mental process, relation) that is predicated of the Subject" (Halliday, 1998, p. 79: Halliday \& Matthiessen, 2014, p. 152); Complement "the element that has the potential of being Subject but is not" (Halliday, 1998, p. 80; Halliday \& Matthiessen, 2014, p. 153) or the complementary component which "completes the action specified by the verb" (Crystal, 2008, p. 67); and Adjunct - the element that "has not got the potential of being Subject" (Halliday, 1998, p. 80; Halliday \& Matthiessen, 2014, p. 154), because it is "an optional or secondary element in a construction" (Crystal, 2008, p. 12).

One point should be noted here; that is, looked at from the point of view of tenor of discourse, there are three parties (voices) involved in the stanza representing two distinct pairs or dyads of communicators. The first pair is between the poetess and general readers, and the poetess adopts herself as an equal of her readers reflected in Tôi (I) $\leftrightarrow$ readers (unseen). The second pair is between the poetess and her ex-lover, and Figure 4

Textual Meaning of the Stanza

(1)

\begin{tabular}{|l|l|l|l|}
\hline Một mùa thu trước & mồi hoàng hôn & Nhặt & cánh hoa roi \\
\hline Theme & Rheme \\
\hline Given & \multicolumn{3}{|c|}{ New } \\
\hline
\end{tabular}

the poetess adopts herself also as an equal of him reflected in Tôi $\leftrightarrow$ ngươ $i$ (he) (also unseen). And since the poetess is the giver of the information, in the first four clauses, the first personal pronoun Tôi takes on the function of Subject (which is left out in the first three clauses). In clause (5), the poetess' ex-lover nguoo $i$ (him) appears, taking on the function of Subject, but it is the Subject of a hypotactic (dependent) clause: ngườ đến với yêu đưong.

From the above analysis, we can summarize the interpersonal meaning of the stanza realized in mood structures as follows:

- clause (1) has the configuration of Adjunct 1 (Một mùa thu truoóc) ^ Adjunct 2 (mỗi hoàng hôn) ^ Predicator Nhặt ${ }^{\wedge}$ Complement (cánh hoa roi);

- clause (2): Predicator (chẳng thấy) ${ }^{\wedge}$ Complement (buồn);

- clause (3): Predicator (Nhuộm) ^ Complement (ánh nắng tà)^ Adjunct (qua mái tóc);

- clause (4): Subject $(T \hat{i} i)^{\wedge}$ Predicator $($ chơ);

- clause (5): Subject (nguòii) ^ Predicator (đến) ^ Adjunct (với yêu duong).

\subsubsection{The Textual Metafunction}

We are now moving on to examine the stanza from the point of view of the textual metafunction, analyzing the organization of information in the clauses in terms of Theme-Rheme, Given - New. The result is provided in Figure 4 below. 
(2)

\begin{tabular}{|l|l|}
\hline chẳng thấy & buồn \\
\hline Theme & Rheme \\
\hline Given $\longrightarrow$ New \\
\hline
\end{tabular}

(3)

\begin{tabular}{|l|l|l|}
\hline Nhuộm & ánh nắng tà & qua mái tóc \\
\hline Theme & Rheme \\
\hline Given & \\
\hline
\end{tabular}

(4)

\begin{tabular}{|l|l|}
\hline Tôi & chò \\
\hline Theme & Rheme \\
\hline Given & $\longrightarrow \quad$ New \\
\hline
\end{tabular}

(5)

\begin{tabular}{|l|l|l|}
\hline ngườ & đến & với yêu đưong \\
\hline Theme & Rheme \\
\hline Theme & \\
\end{tabular}

The analysis of the stanza in Figure 4 shows that the basic unit of language in use is not a word or a clause but a "text", and the textual elements in language are the choices through which the speaker or writer produces texts and uses language appropriate to the context. In this textual metafunction, the clause is said to be organized as a message. As a message, the clause, in normal or unmarked conditions, begins with the element assigned the function of Theme - the fulcrum or starting point of the message. The remainder of the message - the element which tells about the Theme, is referred to (to use the terminology of the Prague school of linguists) as Rheme. "A message consists of a Theme combined with a Rheme" (Halliday 1998, p. 28; see also Cao, 2004; V. V. Hoang, 2007).

The analysis in Figure 4 also shows that the Theme-Rheme structure is closely related to another aspect of the textual organization of language referred to in SFL as "information structure" which relates to the two functional components of Given (or Old) and New (information). Like the Theme-Rheme structure, the Given-New structure includes an optional Given (information whose presence in the clause is not required, and which can be recovered from the context) and an obligatory New (information whose presence in the clause is required, because if there is not something new, there would be no information at all). In the Theme-Rheme structure, the Theme is the prominent component which means "here is the heading to what I am saying" and the Rheme means the exposition of the Theme. In contrast, in the Given-New structure, the New is the prominent component which means "this is point of contact with what you know". Under normal conditions, Theme conflates with Given (Theme/Given) and Rheme with New (Rheme/New). (For more detail, see Halliday, 1970, p. 163; see also Halliday, 1998; Halliday \& Matthiessen, 2014). These theoretical statements are true to our analysis for the Theme-Rheme and Given-New structures of the stanza in Figure 4 which can be elaborated in some more detail below.

Clause (1) starts with the two nominal groups Một mùa thu trước and mối hoàng hôn. These elements both function as Theme/Given, and the remaining segment Nhăt cánh hoa rơi functions as Rheme/New. In clause (2), the verbal group chẳng thấy functions as Theme/Given and the adjective buồn as Rheme/New. In clause (3), the verb Nhuôm functions as Theme/Given and the remaining segment ánh nắng tà qua mái tóc as Rheme/New. In clause (4) the first personal pronoun Tô $i$ functions as Theme/Given and the verb chò as Rheme/New. And in clause (5) the third personal pronoun nguoo $i$ functions as Theme/Given and the remaining segment đến với yêu đurơng as Rheme/New. 
A closer inspection of the stanza will reveal that there is a difference between the components assigned the function of Theme/Given in clause (1) and those assigned the same function in clauses (2) and (3) and in clauses (4) and (5). In clause (1), Một mùa thu trước and mỗi hoàng hôn are assigned the function of Circumstance: time 1 and Circumstance: time 2 experientially, Adjunct 1 and Adjunct 2 interpersonally, and Theme/Given textually. In clauses (2) and
(3), in contrast, chẳng thấy and Nhuộm are assigned the function of Process: mental and Process: material experientially, Predicator interpersonally, but Theme/Given textually; and in clauses (4) and (5) Tôi and ngưòi are assigned the function of Actor experientially, Subject interpersonally, but Theme/Given textually. The different components assigned the function of Theme/Given in the clauses of the stanza can be summarized below.
- Clause (1):
- Clauses (2) and (3):
- Clauses (4) and (5):

\subsubsection{The Logical Metafunction}

In Sections 2, 3, and 4, we presented the metafunctions of language and their lexicogrammatical patterns within the clause, in which the groups and phrases together constitute the experiential meaning, the interpersonal meaning, and the textual meaning. In this section, we will be concerned with another aspect of the ideational metafunction - the logical metafunction which relates to "the possibilities of combining messages into the clusters of clauses we call complexes" (Butt et al., 2003, p. 160).

Natural languages contain an inexhaustible resource that allows users to construe not only classes of things such as house, door, rose, history, time, space; qualities, shapes, sizes, and colours such as beautiful, ugly, long, short, round, square, white, black; and quantities (specific and non-specific) such as one, two, three, some, many, all, but also what is going on in the real world, including the inner world of the speaker's own consciousness such as action, event, behavior, relationship, existence, etc. expressed through components taking on the functions of the participant, process, circumstance in the experiential domain as described in Section 2. In daily communication, the speaker rarely focuses on construing things as single phenomena. Rather, he or she makes use of the infinite resource of language to create complex categories such as all those five beautiful white chickens, in which the Thing (chickens) is characterized by a combination of qualities (beautiful and white), quantities (all and five) and the location of the Thing relative to the speaker (those) (for more detail of the meaning and structure of the nominal group, see Halliday 1998, pp. 353-77; Halliday \& Matthiessen, 2014, pp. 364-96 in relation to English, and T. C. Nguyen, 1999; V. V. Hoang, 2006 in relation to Vietnamese); or If you came early, remember to wait for me, where two single events If you came early and remember to wait for me are combined to create a complex forming an inter-clausal logicosemantic relationship of the pattern "If $\mathrm{A}$ then B". Thus, clause complex is a resource for creating systems of general logicosemantic relationships such as "parataxis", "hypotaxis", "expansion", and "projection". "parataxis" refers to the relationship of equal status between clauses in the clause complex as in ||| (1) John didn't wait; \| (2) he ran away 1||; "hypotaxis": the relationship of unequal status between clauses in the clause complex where there is one main (primary) 
clause and one or more than one dependent (or secondary) clauses as in $\| \mid \alpha$ John ran away \| $\beta$ because he was scared II; "expansion" which includes relationships such as "elaboration": one clause elaborates the meaning of the other by describing it or further specifying it as in ||| (1) She didn't answer; $\|=$ (2) she said nothing; "extension": one clause extends the meaning of the other by adding something new to it as in $\| \mid$ (1) I stayed at home; $\|+(2)$ and my wife went to work |||; "enhancement": one clause qualifies the meaning of the other by reference to time, place, manner, etc. as in || (1) She had been reading for two hours \| $\mathrm{x}(2)$ when he came U||; and "projection" which includes two modes: "quoting" ("direct speech" in traditional grammar): one clause (the projecting clause) projects the other clause(s) (the projected clause(s)) where the projected clause(s) represent(s) that which is/are said, and the projecting clause and projected clause(s) are of equal status as in || (1) She said to him: || "(2) "Go away." ||; and "reporting" ("indirect speech" in traditional grammar): one clause projects the other clause(s) where the projected clause(s) report(s) what is/are said, and the projecting clause and the projected clause(s) are of unequal status as in $\| \mid(1) \alpha$ She thought that || (2) $\beta$ he would go away ||| (for more Figure 5

Logico-Semantic Relationships of the Clause Complex in the Stanza

\begin{tabular}{|c|c|}
\hline$x \beta$ & $\begin{array}{l}\text { || (1)ß Một mùa thu trước mỗi hoàng hôn } \\
\text { Nhặt cánh hoa rơi } \|+(2) \beta \text { chẳng thấy buồn } \| \\
+ \text { (3)ß Nhuộm ánh nắng tà qua mái tóc } \|\end{array}$ \\
\hline$\alpha$ & (4) $\alpha$ Tôi chờ $\|+(5) \beta$ người đến với yêu đương. \|| \\
\hline
\end{tabular}

If we do the bracketing analysis, the logico-semantic relationships of the clauses of the stanza can be presented as follows:

$$
\mathrm{x} \beta((1) \beta+(2) \beta+(3) \beta)^{\wedge} \alpha((4) \alpha+(5) \beta)
$$

In the above analysis, we have been concerned only with the logico-semantic detail, see Halliday, 1985, 1998; Halliday \& Matthiessen, 2014).

Turning now to the logical meaning of the stanza, it can be seen that in Section 2, we have only interpreted the stanza as the representation of experiential meaning in single clauses, one by one. However, from the point of view of the logical metafunction, we will see that the wording of the stanza forms a clause complex with two layers of logico-semantic relationship. The first layer consists of three clauses: ||| (1) Một mùa thu trước mỗi hoàng hôn, Nhặt cánh hoa rơi $\|$ (2) chẳng thấy buồn, \| (3) Nhuộm ánh nắng tà qua mái tóc\|; these are in hypotactic relationship of enhancement with the clause complex consisting of two clauses: ||| (4) Tô $i$ chờ || (5) người đến với yêu đương |||, represented by the sequence $\mathrm{x} \beta \wedge \alpha$. The second layer consists of two types of logicosemantic relationship; the first type is the paratactic relationship of extension between clauses (1), (2) and (3), represented by the sequence (1) $\beta+(2) \beta+(3) \beta$; and the second type is the hypotactic relationship of extension where (5) extends the meaning of (4), represented by the sequence (4) $\alpha+(5) \beta$. These layers of logico-semantic relationship of the clause complex in the stanza can be shown in Figure 5 below. relationships of the expansion mode. There is another mode of logico-semantic relationship which contributes to the formation of the logical metafunction of language: that of projection mode. Let us consider the second part of the third stanza of the poem below. 
(6)

\begin{tabular}{|l|l|l|l|l|l|l|}
\hline || Bảo & rằng: & $\|$ "Hoa, & dáng & nhu & tim & võ $\|$ \\
\hline say & that & flower & appearance & like & heart & break \\
\hline
\end{tabular}

(He) said that "the fallen flower looks like a broken heart".

(8)

\begin{tabular}{|l|l|c|l|l|l|l|}
\hline$\|$ Anh & sơ & $\|$ tình & ta & cũng & vó & thô $i$ ' || \\
\hline brother (senior) & fear & love & we & also & break & stop \\
\hline
\end{tabular}

I'm afraid that our love will be broken too.

The above lines of the third stanza constitute a clause complex of projection mode in which clause (6) Bảo rằng is the reporting clause, and clauses (7) Hoa, dáng nhu tim võ, (8) Anh sơ, and (9) tình ta cüng $v \tilde{o}$ thô $i$ are the reported ones. Like the first stanza, this clause complex of projection consists of two layers of logico-semantic relationship. The first layer is the projection relationship of "quoting" in which clause (6) is the projecting clause, and clauses (7), (8), and (9) are the projected ones, represented by the pattern $(6) \alpha^{\wedge}$ “"(7) $\beta 1+(8,9) \beta 2$. The second layer is the projection relationship of "reporting" in which clause (8) is the reporting clause, and clause (9) is the reported one, represented by the pattern (8) $\wedge$ '(9). The projection relationships in the clause complex can be represented by the following pattern:

$$
\alpha(6) \wedge \text { “'(7) } \beta 1+\left((8) \beta 2 \alpha^{\wedge} \text { '(9) } \beta 2 \beta\right) .
$$

\section{Conclusion}

In this paper, we have made an attempt to explore how metafunctions of language are theorized in SFL, and how the theory of metafunctions of language are applied to the analysis of text in social context. To lay the ground for our work, we have examined a number of formal as well as non-SF models of language functions. It is clear from our examination that although these models look very different and they use different terminologies; they have one important thing in common: they all recognize that language is multifunctional. However, how many and what functions language has depend largely on how scholar of each model approached language: Malinowski approached language from the point of view of ethnography, and he recognized four language functions: speech of action, narrative, phatic communion, and the ritual use of words; Bühler approached language from the point of view of psychology, and he recognized three language functions: expressive function, conative function, and representational function; Jakobson approached language from the point of view of communication process, and he recognised six language functions: referential function, emotive function, conative function, phatic function, poetic function, and metalingual function; Britton approached language from the point of view of education, and he recognized three language functions: expressive function, transactional function, and poetic function; and Morris approached the problem from the point of view of the evolution of communication, and he recognized four language functions: information talking, mood talking, exploratory talking, and grooming talking. In discussing the advantages of these models, we have as well pointed out their drawbacks, the most inherent and visible one among them is that except for the traditional grammar models, all these models have constructed some kind of functional framework in non-linguistic 
terms, conceptualizing the functions of language from the outside and using this as a grid for interpreting the different ways in which people use language. That explains why in their interpretations, function of language is equated with use of language.

Having explored functions of language as conceptualized in formal and non-SF models, we turned to look in some detail at the model of functions of language as theorised in SFL by the eminent linguist M.A.K. Halliday. Our examination of the model has shown that although SFL shares with the other models in that it recognises that language is multifunctional; it differs from the other models in a number of ways. First, SFL is a theory of language that relates the functions of language the child employs to satisfy his or her needs to the generalized functions of language of the grown-up. Secondly, in SFL function is interpreted not just as the use of language, but as a fundamental property of language (Halliday \& Hasan, 1989, p. 17) hence the concept "metafunctions" of language. And thirdly, as evident in our analysis of the poem "Hai sắc hoa ti-gôn", the applicability potential of SFL is vast. When scholars of the other models claim that their models of language functions should ultimately be related to a semiotic or pragmatic theory, and this remains largely programmatic, Halliday's multifunctional model goes some way towards consistently relating linguistics to sociology. Conceptualizing language as a social semiotic system, Halliday is able to incorporate the social dimension into his linguistic theory and he holds that without it the nature of language and language development cannot satisfactorily be explained. Further, he has developed a number of concepts bridging the social system and the linguistic system such as "register", "system or semantic network", and, in particular, "metafunction" (see Davidse, 1987). As has been shown in our study, Halliday's concept of metafunctions of language is much deeper and more abstract than "functions of language equated with specific uses of language" in most formal and non-SF models. It is the concept that faces upwards to the social context (context of situation and context of culture), and downwards to the linguistic system (semantics, lexicogrammar, and phonology). Thus, whereas in the work of the formal and non-SF scholars, the references of language to context of situation and context of culture remain largely ad hoc, Halliday has offered a comprehensive linguistic theory that relates language to social situation and culture systematically, enabling users to apply the SFL theory to their relevant fields of study to serve their specific purposes. Our analysis for the meanings of the two stanzas of the poem "Hai sắc hoa ti-gôn", using Halliday's metafunctions of language as the theoretical framework has in part suggested the applicability potential of SFL in text analysis, enriching the already vast applicability potential of the SFL theory in other fields of human knowledge such as language description, language teaching and learning, language comparison, and translation studies.

\section{References}

Austin, J. L. (1962). How to do things with words. Oxford University Press.

Britton, J. (1993). Language and learning (2nd ed.). Boynton/Cook Publishers Inc.

Butt, D., Fahey, R., Feeze, S., Sprink, S., \& Yallop, C. (2003). Using functional grammar: An explorer's guide (2nd ed.). Robert Burton Printers.

Bühler, K. (1934). Sprachtheorie: die Darstellungsfunktion de Sprache (The theory of language: The representational function of language). Jena.

Cao, X. H. (2004). Tiếng Việt: So thảo ngũ pháp chức năng (Vietnamese: An outline of functional grammar). Nhà xuất bản Giáo dục.

Crystal, D. (2008). A dictionary of linguistics and phonetics (3rd ed.). Blackwell. 
Davidse, K. (1987). M. A. K. Halliday's functional grammar and the Prague school. In R. Dirven \& V. Fried (Eds.), Linguistic and literary studies in Eastern Europe: Functionalism in linguistics (Vol. 20, pp. 39-79). John Benjamins.

De Saussure, F. (1983). Course in general linguistics (R. Harris, Trans.). Stanford University Press.

Diệp, Q. B. (1987). Câu đơn tiếng Việt (The simple sentence in Vietnamese). Nhà xuất bản Giáo dục.

Firth, J. R. (1957). Papers in linguistics 1934-1951. Oxford University Press.

Firth, J. R. (1968). Selected papers of J. R. Firth 1952-59. Longman.

Fries, P. H. (1981). On the status of theme in English: Arguments from discourse. Forum Linguisticum, 6(1), 1-38.

Halliday, M. A. K. (1970). Language structure and language function. In J. Lyons (Ed.), New horizons in linguistics (pp. 140-64). Penguin.

Halliday, M. A. K. (1973). Explorations in the functions of language (Explorations in language study). Edward Arnold.

Halliday, M. A. K. (1975). Learning how to mean: Explorations in the development of language. Edward Arnold.

Halliday, M. A. K. (1978). Language as social semiotic: The social interpretation of language and meaning. Edward Arnold.

Halliday, M. A. K. (1985). An introduction to functional grammar (1st ed.). Edward Arnold.

Halliday, M. A. K. (1994). Systemic theory. In R. E. Asher (Ed.), The encyclopedia of language and linguistics (pp. 4505-8). Pergamon Press.

Halliday, M. A. K. (1998). An introduction to functional grammar (2nd ed.). Edward Arnold.

Halliday, M. A. K., \& Hasan, R. (1976). Cohesion in English. Longman.

Halliday, M. A. K., \& Hasan, R. (1989). Language, context, and text: Aspects of language in a social-semiotic perspective. Oxford University Press.

Halliday, M. A. K., \& Matthiessen, C. M. I. M. (2014). Halliday's introduction to functional grammar (4rd ed.). Routledge.

Halliday, M. A. K., McInntosh, A., \& Strevens, P. (1964). The linguistic sciences and language teaching. Longmans.
Hasan, R. (2011). Selected works of Ruqaiya Hasan on applied linguistics. Foreign Language Teaching and Research Press.

Hasan, R., \& Perrett, G. (1994). Learning to function with the other tongue: A systemic functional perspective on second language teaching. In T. Odlin (Ed.), Perspectives on pedagogical grammar (pp. 179-226). Cambridge University Press.

Hoang, V. V. (2006). Nominalisation in scientific discourse and the problems related to the translation of nominal group from English into Vietnamese. VNU Journal of Science, $5 E, 11-23$.

Hoang, V. V. (2012). An experiential of the Vietnamese clause. Nhà xuất bản Giáo dục.

Hoang, V. V. (2018a). "Bánh trôi nước" and three English versions of translation: A systemic functional comparison. VNU Journal of Foreign Studies, 34(4), 1-35. https://doi.org/10.25073/25252445/vnufs.4279

Hoang, V. V. (2018b). The language of school science textbooks: A transitivity analysis of seven lessons (texts) in Biology 8. Linguistics and the Human Sciences, 14(1), 1-35. https://doi.org/10.1558/lhs.31751

Hoàng, V. V. (2007). Về khái niệm đề ngữ trong ngôn ngữ học chức năng (On the concept of theme in functional linguistics). Tạp chí Ngôn ngũu, 2(213), 1-10.

Hoàng, P. et al. (2002). Tù diển tiếng Việt (A dictionary of Vietnamese) (In lần thứ 8). Nhà xuất bản Đà Nẵng.

Hoàng, T. P. (1980). Ngũ pháp tiếng Việt: Câu (A grammar of Vietnamese: The sentence). Nhà xuất bản Đại học và trung học chuyên nghiệp.

Jakobson, R. (1960). Closing statement: Linguistics and poetics. In T. A. Sebeok (Ed.), Style in language (pp. 1-27). MIT Press \& Wiley. https://silo.tips/download/12392

Kaushanskaya, V. L. et al. (2008). A grammar of the English language. Airis Press.

Malinowski, B. (1923). Supplement I: The problem of meaning in primitive languages. In C. K. Ogden \& I. A. Richards (Eds.), The meaning of meaning: A study of the influence of language upon thought and of the science of symbolism (pp. 298-336). Routledge \& Kegan Paul.

Martin, J. R. (1992). English text: System and structure. John Benjamins. 
Matthiessen, C. M. I. M. (1992). Interpreting the textual metafunction. In M. Davis \& L. Ravelli (Eds.), Advances in systemic functional linguistics: Recent theory and practice (pp. 37-81). Pinter Publishers.

Matthiessen, C. M. I. M. (1995). Lexicogrammatical cartography: English systems. International Language Sciences Publishers.

Matthiessen, C. M. I. M., Teruya, K., \& Lam, M. (2010). Key terms in systemic functional linguistics. Continuum.

Morris, D. (1999). The Naked Ape. Delta.

Neubert, A. (2000). Theory and practice of translation studies revisited: 25 years of translator training in Europe. In A. Beeby, D. Ensinger \& M. Presas (Eds.), Investigating translation: Selected papers from the $4^{\text {th }}$ International Congress on Translation, Barcelona, 1998 (pp. 13-26). John Benjamins.
Nguyễn, K. T. (1964). Nghiên cúu về ngũ pháp tiếng Việt (Studies in Vietnamese grammar) (Tập 2). Nhà xuất bản Khoa học xã hội.

Nguyễn, T. C. (1999). Ngũ pháp tiếng Việt: Tiếng tù ghép - đoản ngũ (A Vietnamese grammar: Words - compounds - phrases). Nhà xuất bản Đại học Quốc gia Hà Nội.

Ogden, C. K., \& Richards, I. A. (1923). The meaning of meaning: A study of the influence of language upon thought and the science of symbolism. Routledge \& Kegan Paul.

Searle, J. (1969). Speech acts. Cambridge University Press.

Thompson, G. (2014). Introducing functional grammar (3rd ed.). Routledge.

Wilson, H. (2007). American English grammar. Homibooks Publication Company.

\title{
"CÁC SIÊU CHỨC NĂNG NGÔN NGŨ" TRONG NGÔN NGŨ’ HỌC CHÚC NĂNG HỆ THỐNG: KHUNG LÍ THUYẾT DÙNG ĐỀ GIẢI THÍCH Ý NGHĨA CỦA NGÔN BẢN TRONG NGÔN CẢNH XÃ HộI
}

\author{
Hoàng Văn Vân
}

Trung tâm Nghiên cứu giáo dục ngoại ngũu, ngôn ngũ và quốc tế họ, Trường Đại học Ngoại ngũu, ĐHQGHN, Phạm Văn Đồng, Cầu Giấy, Hà Nội, Việt Nam

Tóm tắt: Bài báo này liên quan đến cách “các siêu chức năng ngôn ngữ” được học giả M.A.K. Halliday phát triển như thế nào trong lí thuyết Ngôn ngữ học Chức năng Hệ thống, và khung lí thuyết siêu chức năng được sử dụng như thế nào để phân tích và giải thích ý nghĩa của ngôn bản trong ngôn cảnh xã hội. Bài báo gồm năm phần. Phần một giới thiệu chủ đề của bài báo. Phần hai kiểm tra vắn tắt khái niệm "các chức năng ngôn ngữ" trong các mô hình ngôn ngữ học hình thức và phi chức năng hệ thống. Phần ba nghiên cứu chi tiết khái niệm "các siêu chức năng ngôn ngữ" trong mô hình Ngôn ngữ học Chức năng Hệ thống. Nghiên cứu chỉ ra rằng không giống với các mô hình ngôn ngữ học hình thức và phi chức năng hệ thống, Ngôn ngữ học Chức năng Hệ thống khái luận hoá khái niệm "các siêu chức năng ngôn ngữ" không chỉ như là "các cách sử dụng ngôn ngữ" mà còn như là một đặc tính căn bản của chính ngôn ngữ. Để minh hoạ cho khả năng ứng dụng của khung lí thuyết siêu chức năng vào việc phân tích và giải thích ý nghĩa của ngôn bản trong ngôn cảnh xã hội, Phần bốn tiến hành phân tích hai khổ thơ trong bài thơ tiếng Việt nổi tiếng 'Hai sắc hoa ti-gôn'. Phần năm tóm tắt lại những nội dung đã được nghiên cứu trong bài báo, chỉ ra những lợi thế của khung lí thuyết đa siêu chức năng của Halliday. Nghiên cứu này nhằm góp phần vào sự hiểu biết của chúng ta về ngôn ngữ như là một hệ thống các siêu chức năng, mở ra tiềm năng to lớn cho việc áp dụng mô hình Ngôn ngữ học Chức năng Hệ thống vào giảng dạy, học tập, và nghiên cứu ngôn ngữ.

Tù khoá: các mô hình hình thức và phi chức năng hệ thống, các siêu chức năng ngôn ngữ, Ngôn ngữ học Chức năng Hệ thống, ý nghĩa của ngôn bản trong ngôn cảnh xã hội 


\section{Appendix 1}

\section{Source of Data for Illustration}

T. T. Kh. (1937, October 30). Hai sắc hoa ti-gôn. Tiểu thuyết thứ bảy, (179). Retrieved June 27, 2020, from https://www.thivien.net/T-T-Kh/Hai-s\%E1\%BA\%AFc-hoa-tig\%C3\%B4n/poemWHkchEOXvnLcnoBDnAnHww.

\section{Appendix 2}

\section{Clause Complexes and Clause Simplexes and Their Logico-Semantic Relationships}

\section{Stanza 1}

\begin{tabular}{|l|l|}
\hline$x \beta \wedge$ & $\begin{array}{l}\| \mid(1) \beta \text { Một mùa thu trước mỗi hoàng hôn } \\
\text { Nhặt cánh hoa rơi } \|+(2) \beta \text { chẳng thấy buồn } \| \\
+(3) \beta \text { Nhuộm ánh nắng tà qua mái tóc } \|\end{array}$ \\
\hline$\alpha$ & (4) $\alpha$ Tôi chờ $\|+(5) \beta$ người đến với yêu đương. \|\| \\
\hline
\end{tabular}

\section{Stanza 3}

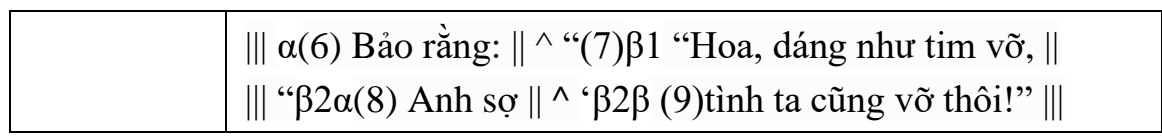

\section{Appendix 3}

\section{The Notational Conventions}

- The symbol $\| \mid$ indicates the boundary of the clause complex.

- The symbol $\|$ indicates the boundary of the clause simplex.

- The bold-typed Roman numerals (I), (II), (III), etc. indicate clause complexes.

- The Arabic numerals (1), (2), (3), etc. indicate clause simplexes.

- The Greek letters $\alpha$ and $\beta$ indicate hypotactic relationship between clauses where $\alpha$ indicates the main (or primary) clause and $\beta$ indicates the dependent (or secondary) clause.

- The symbol = indicates the expansion: elaboration relationship between clauses in the clause complex.

- The symbol + indicates the expansion: extension relationship between clauses in the clause complex.

- The symbol $x$ indicates the expansion: enhancement relationship between clauses in the clause complex.

- The symbol " indicates quoted clause in the quoting clause complex.

- The symbol ' indicates reported clause in the reporting clause complex. 